\title{
Spectrophotometric Determination of Gallium(III) with 4-(2-Pyridylazo)-resorcinol and Nitron
}

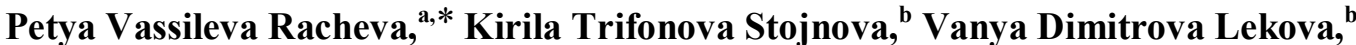 \\ and Atanas Nikolov Dimitrov \\ ${ }^{a}$ Departament of Chemistry and Biochemistry, Medical University - Plovdiv, \\ 15 A Vassil Aprilov Blvd., 4002 Plovdiv, Bulgaria \\ ${ }^{\mathrm{b}}$ Departament of General and Inorganic Chemistry, University of Plovdiv "Paisii Khilendarski", \\ 24 Tsar Assen Str., 4000 Plovdiv, Bulgaria
}

RECEIVED FEBRUARY 10, 2014; REVISED FEBRUARY 9, 2015; ACCEPTED APRIL 17, 2015

\begin{abstract}
The formation and liquid-liquid extraction of ion-association complex between gallium(III) 4-(2-pyridylazo)-resorcinol (PAR) - 1,4-diphenyl-3-(phenylamino)-1H-1,2,4-triazole (nitron, Nt), water and chloroform were studied. The optimum conditions for gallium(III) extraction as an ion-association complex, $(\mathrm{NtH})^{+}\left[\mathrm{Ga}^{3+}(\mathrm{PAR})_{2}\right]^{-}$, were found: $\mathrm{pH}$, concentration of the reagents and shaking time. The following key constants were calculated: constant of extraction $\left(\log K_{e x}=6.28 \pm 0.07\right)$, constant of association $(\log \beta=4.98 \pm 0.05)$, constant of distribution $\left(\log K_{D}=1.30 \pm 0.02\right)$ and recovery factor $(R / \%$ $=95.17 \pm 0.02$ ). Beer's law is obeyed for $\mathrm{Ga}(\mathrm{III})$ concentration up to $0.8 \mu \mathrm{g} \mathrm{cm}{ }^{-3}$ with apparent molar absorptivity of $(10.3 \pm 0.4) \times 10^{4} \mathrm{dm}^{-3} \mathrm{~mol}^{-1} \mathrm{~cm}^{-1}$ at $\lambda_{\max }=510 \mathrm{~nm}$. Some additional characteristics, such as limit of detection ( $\mathrm{LOD}=0.072 \mu \mathrm{g} \mathrm{cm}^{-3}$ ), limit of quantification ( $\mathrm{LOQ}=0.24 \mu \mathrm{g} \mathrm{cm}^{-3}$ ) and Sandell's sensitivity $\left(S S=0.000675 \mathrm{ng} \mathrm{cm}^{-2}\right)$ were estimated as well.
\end{abstract}

Keywords: gallium, ternary complex, solvent extraction, spectrophotometry, nitron

\section{INTRODUCTION}

Gallium is a post-transition metal of strategic importance for various priority areas of technology and science. It is known that it forms a colored anionic chelates with certain azo dyes \{(4-(2-pyridylazo)resorcinol (PAR) and 4-(2-thiazolylazo)-resorcinol (TAR)\}, which are associated with bulky organic cations to form a ternary ion associated complexes. These compounds are poorly soluble in water, but readily extractable in organic solvents, and this makes it possible to apply for the purpose of extractionspectrophotometric analysis. ${ }^{1-16}$ In our long term studies on ion associates a number of metals, such organic bases used are mono- and ditetrazolium salts. In this regard, studies have been conducted with the ion associates of $\mathrm{Ga}(\mathrm{III})$, which suffer the influence of the ligands, the influence of mono- and diterazolium bases, and of the various substituents on the molecule of the tetrazolium salt on the equilibria and the analytical characteristics of the test extraction systems. Thus, the best characteristics proved ionic associates formed between the anionic chelate of $\mathrm{Ga}(\mathrm{III})$ and PAR with the monotetrazolium salts: 3-(4,5-dimethylthiazol-2-yl)-2,5diphenyl-2H-tetrazolium bromide (tiazolyl blue tetrazolium, MTT), 3-(2-naphtyl)-2,5-diphenyl-2H-tetrazolium chloride (tetra-zolium violet, TV) and 2,3,5triphenyltetrazolium chloride (TTC). ${ }^{17-19}$ In this work are presented research on the extraction system $\mathrm{Ga}$ (III)-PAR- $\mathrm{Nt}-\mathrm{H}_{2} \mathrm{O}-\mathrm{CHCl}_{3}$, which tetrazolium cation is replaced with triazolium.

$\mathrm{Nt}$ (Figure 1) is a low-cost and low-toxic analytical reagent that has been commercially available for more than a century; however, some novel aspects of its chemical nature have been recently disclosed..$^{15}$<smiles>Oc1ccc(/N=N/c2ccccn2)c(O)c1</smiles>

(a)<smiles>CN(c1ccccc1)c1nn(-c2ccccc2)c[n+]1-c1ccccc1</smiles>

(b)
Figure 1. (a) 4-(2-Pyridylazo)-resorcinol (PAR); (b) 1,4diphenyl-3-(phenyllamino)-1H-1,2,4-triazole (nitron, $\mathrm{Nt}$ ).

\footnotetext{
* Author to whom correspondence should be addressed. (E-mail: racheva80@abv.bg)
} 
It should be said that extraction systems containing both PAR and Nt have been weakly studied. To the best of our knowledge, the only reported investigations in this field concern vanadium(V) ${ }^{16}$ and cobalt(II) ${ }^{20}$ extraction and spectrophotometric determination.

\section{EXPERIMENTAL}

The stock gallium(III) solution was prepared by heating for 20 min a known amount $(0.1346 \mathrm{~g})$ of $\mathrm{Ga}_{2} \mathrm{O}_{3}$ (KochLight Laboratories Ltd., 99,99\% in $37 \% \mathrm{HCl}\left(20 \mathrm{~cm}^{3}\right)$. After cooling, the obtained clear solution was collected into a $100-\mathrm{cm}^{3}$ calibrated flask and diluted to the mark with $6.5 \mathrm{~mol} \mathrm{dm}^{-3}$ solution of $\mathrm{HCl}^{18}$ Fresh working solutions $\left(50 \mathrm{~cm}^{3}\right)$ were prepared every day by mixing an aliquot of the stock solution, $0.3 \mathrm{~cm}^{3}$ of $6.5 \mathrm{~mol} \mathrm{dm}^{-3}$ solution of $\mathrm{HCl}$ and distilled water. solution.

PAR (Fluka AG, p.a.), 2.0× $10^{-3} \mathrm{~mol} \mathrm{dm}^{-3}$ aqueous

Nitron ( $\geq 97 \%$, Fluka), $3.5 \times 10^{-4} \mathrm{~mol} \mathrm{dm}^{-3}$ chloroform solution.

Buffer solution, prepared by mixing $2.0 \mathrm{~mol} \mathrm{dm}^{-3}$ aqueous solutions of $\mathrm{CH}_{3} \mathrm{COOH}$ and $\mathrm{NH}_{4} \mathrm{OH}$.

Chloroform (additionally distilled).

WTW pH 720, Inolab.

Ultrospec 3300 pro UV / visible spectrophotometer (Amersham Biosciences), equipped with $10 \mathrm{~mm}$ path-length cells.

\section{Procedure for Establishing the Optimum Operating Conditions}

Aliquots of $\mathrm{Ga}$ (III) solution, PAR solution (up to $\left.1.2 \mathrm{~cm}^{3}\right)$, and buffer solution $\left(5.0 \mathrm{~cm}^{3} ; \mathrm{pH}\right.$ ranging 3.5 to 9.3 ) were introduced into $250-\mathrm{cm}^{3}$ separatory funnels. The resulting solutions were diluted with distilled water to a total volume of $10 \mathrm{~cm}^{3}$. Appropriate amounts of $\mathrm{Nt}$ solution and chloroform were added in a total volume of $10 \mathrm{~cm}^{3}$. Then the funnels were shaken for a fixed time (up to $5.0 \mathrm{~min}$ ). A portion of the organic extract was filtered through a filter paper (to prevent the opportunity of water droplets transfer) into a cell and the absorbance read against a blank.

Table 1. Optimum conditions and analytical characteristics of the Ga(III)-PAR-Nt-water-chloroform system

\begin{tabular}{|c|c|}
\hline Optimum conditions & Analytical characteristics \\
\hline Wavelength - & Molar absorptivity $-\varepsilon=(10.3$ \\
\hline $510 \mathrm{~nm}$ & $\pm 0.4) \times 10^{4} \mathrm{dm}^{3} \mathrm{~mol}^{-1} \mathrm{~cm}^{-1}$ \\
\hline $\mathrm{pH}=6.87$ & Beer's law - range up to \\
\hline (acetate buffer) & $0.8 \mu \mathrm{g} \mathrm{cm}^{-3}$ \\
\hline$c(\mathrm{PAR})=$ & Limit of detection - \\
\hline $2.0 \times 10^{-4} \mathrm{~mol} \mathrm{dm}^{-3}$ & $0.072 \mu \mathrm{g} \mathrm{cm}^{-3}$ \\
\hline$c(\mathrm{Nt})=$ & Limit of quantification - \\
\hline $3.0 \times 10^{-4} \mathrm{~mol} \mathrm{dm}^{-3}$ & $0.24 \mu \mathrm{g} \mathrm{cm}^{-3}$ \\
\hline $\begin{array}{l}\text { Shaking time - } \\
\quad 60 \mathrm{sec}\end{array}$ & $\begin{array}{c}\text { Sandell's sensitivity - } \\
0.000675 \mathrm{ng} \mathrm{cm}^{-2}\end{array}$ \\
\hline
\end{tabular}

\section{Procedure for Determination of the Distribution Constant}

The distribution constant $K_{D}$ was found from the ratio $K_{D}=A_{1} /\left(A_{3}-A_{1}\right)$, where $A_{1}$ and $A_{3}$ are the absorbances (measured against blanks) obtained after a single and triple extraction, respectively. The single extraction and the first stage of the triple extraction were performed under the optimum extraction-spectrophotometric conditions (Table 1). The organic layers were transferred into $25-\mathrm{cm}^{3}$ calibrated flasks and the flask for the single extraction was brought to volume with $\mathrm{Nt}$ solution. The second stage of the triple extraction was performed by adding another $10 \mathrm{~cm}^{3}$ portion of the $\mathrm{Nt}$ solution to the aqueous phase, which remained after the first stage. After shaking, the organic layer was added to the one obtained after the first stage and the volume was brought to the mark with $\mathrm{Nt}$ solution. Before the spectrophotometric measurement, the calibrated flasks were shaken for homogenization.

\section{RESULTS AND DISCUSSION}

\section{Absorption Spectra}

Spectra of the extracted ternary Ca(III)-PAR-Nt complex and the blank are shown in Figure 2. Maxima are recorded at $510 \mathrm{~nm}$, where the blank absorbs insignificantly. It is shifted to 5-6 $\mathrm{nm}$ as compared to the maximum of the binary Ga-PAR chelate existing in aqueous solution with similar $\left.\mathrm{pH}\left(\lambda_{\operatorname{maxGa}(\mathrm{III0}-\mathrm{PAR}}=504-505 \mathrm{~nm}\right)\right)^{7,8}$

\section{Effect of $\mathbf{p H}$}

The effect of $\mathrm{pH}$ for the extraction of Ga with PAR and $\mathrm{Nt}$ is represented in Figure 3. A buffer solution with a concentration of $2.0 \mathrm{~mol} \mathrm{dm}{ }^{-3}$ (prepared by mixing $2.0 \mathrm{~mol} \mathrm{dm}^{-3}$ aqueous solutions of $\mathrm{CH}_{3} \mathrm{COOH}$ and $\mathrm{NH}_{4} \mathrm{OH}$ ) was applied to control $\mathrm{pH}$. All further experiments were carried out with $5.0 \mathrm{~cm}^{3}$ buffer solution with pH 6.7-6.8.

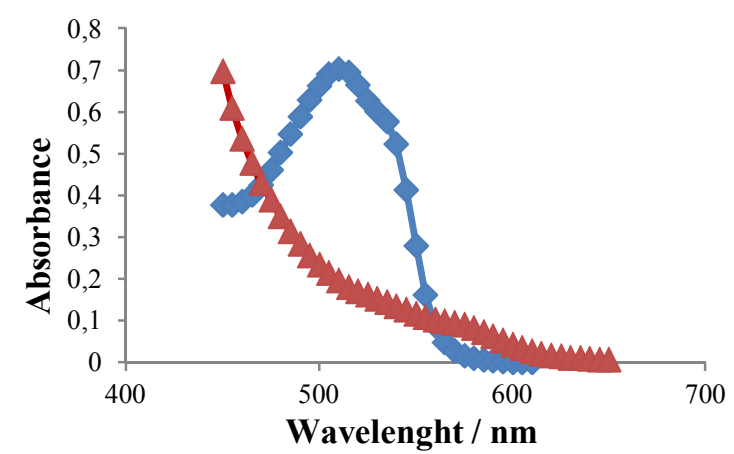

Figure 2. Absorption spectra of the ternary $\mathrm{Ca}(\mathrm{III})-\mathrm{PAR}-\mathrm{Nt}$ complex against blank and blank (PAR-Nt) in chloroform

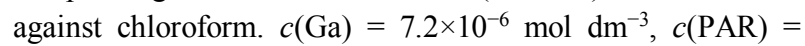
$2 \times 10^{-4} \mathrm{~mol} \mathrm{dm}^{-3}, c(\mathrm{Nt})=3.5 \times 10^{-4} \mathrm{~mol} \mathrm{dm}^{-3}, \mathrm{pH} 6.87$. 


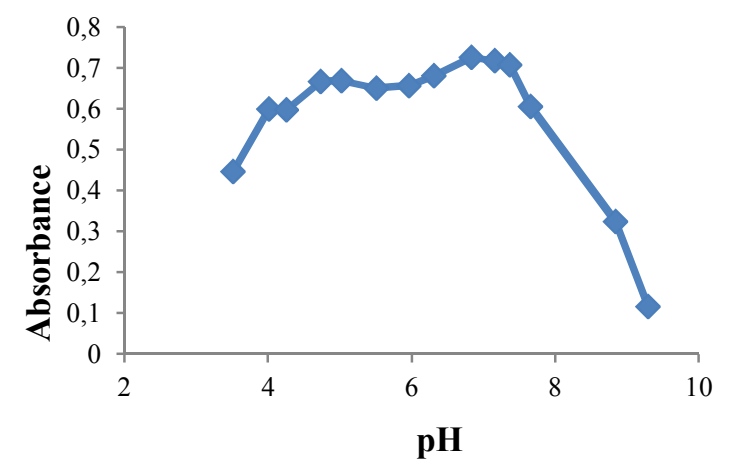

Figure 3. Absorbance of Ga-PAR-Nt complex in chloroform vs. pH of the aqueous phase plot. $c(\mathrm{Ga})=7.2 \times 10^{-6} \mathrm{~mol} \mathrm{dm}^{-3}$, $c(\mathrm{PAR})=2 \times 10^{-4} \mathrm{~mol} \mathrm{dm}^{-3}, c(\mathrm{Nt})=3.5 \times 10^{-4} \mathrm{~mol} \mathrm{dm}^{-3}$, $\lambda=510 \mathrm{~nm}, l=10 \mathrm{~mm}$.

\section{Effect of Shaking Time}

The extraction equilibrium is reached for a short shaking time (about 5 seconds) (Figure 4). To guarantee complete transfer of the complex into organic phase, the authors extracted in their experiments for 60 seconds.

\section{Effect of Reagent's Concentration}

The effect of PAR and Nt concentration on the absorbance are shown in Figure 5 and Figure 6, respectively. For up to $0.8 \mu \mathrm{g} \mathrm{cm}^{-3}$ of $\mathrm{Ga}$, the use about $1.0 \mathrm{~cm}^{3}$ $2 \times 10^{-3} \mathrm{~mol} \mathrm{dm}^{-3}$ PAR (13.9-fold excess) and $7.5 \mathrm{~cm}^{3}$ $3.5 \times 10^{-4} \mathrm{~mol} \mathrm{dm}^{-3} \mathrm{Nt}$ (2.4-fold excess) was found to be sufficient for a complete gallium extraction.

\section{Composition of the Complex and Suggested Formula}

The molar PAR-to-Ga(III) and Nt-to-Ga(III) ratios were determined by the mobile equilibrium method ${ }^{21}$ (Figures 7 and 8), molar ratio method, ${ }^{22}$ and the method of Asmus (Figures 9 and 10). ${ }^{23}$ The results showed that the ternary complex has a composition of $1: 2: 1$ (Ga : PAR : Nt). We suggest the following formula of the extracted ternary species: $(\mathrm{NtH})^{+}\left[\mathrm{Ga}^{3+}(\mathrm{PAR})_{2}\right]^{-}$.

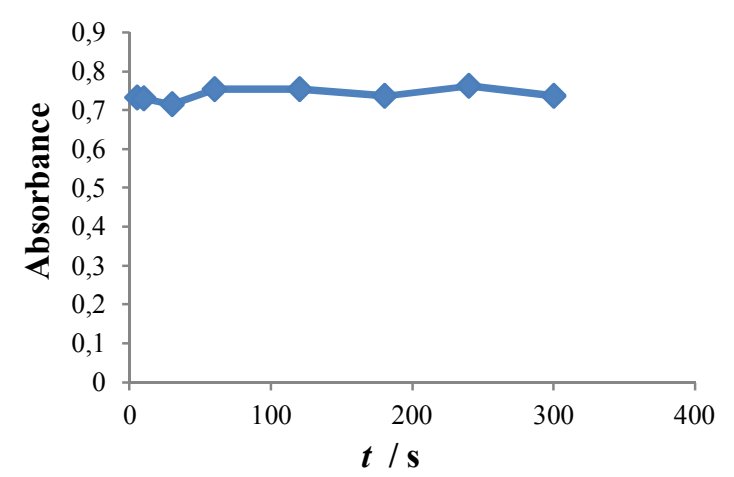

Figure 4. Absorbance of the extracted ternary Ga(III)-PAR-Nt complex $v s$. effect of shaking time. $c(\mathrm{Ga})=7.2 \times 10^{-6} \mathrm{~mol} \mathrm{dm}{ }^{-3}$, $c(\mathrm{PAR})=2 \times 10^{-4} \mathrm{~mol} \mathrm{dm}^{-3}, \mathrm{pH} 6.87, \lambda=510 \mathrm{~nm}, l=10 \mathrm{~mm}$.
In this formula, PAR is in deprotonated form $\left(\mathrm{PAR}^{2-}\right)$, while $\mathrm{Nt}$ is in protonated form $\left(\mathrm{NtH}^{+}\right)$.

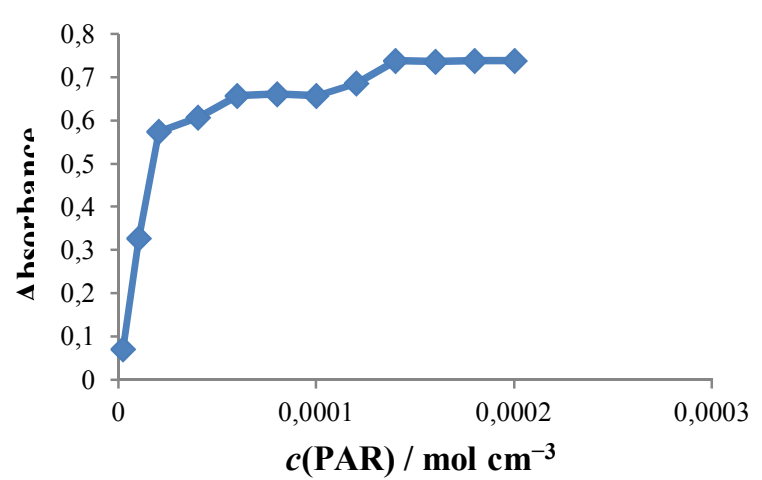

Figure 5. Absorbance of the extracted ternary Ga(III)-PAR-Nt complex vs. concentration of the PAR plots. $c(\mathrm{Ga})=$

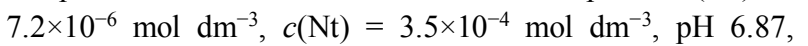
$\lambda=510 \mathrm{~nm}, l=10 \mathrm{~mm}$.

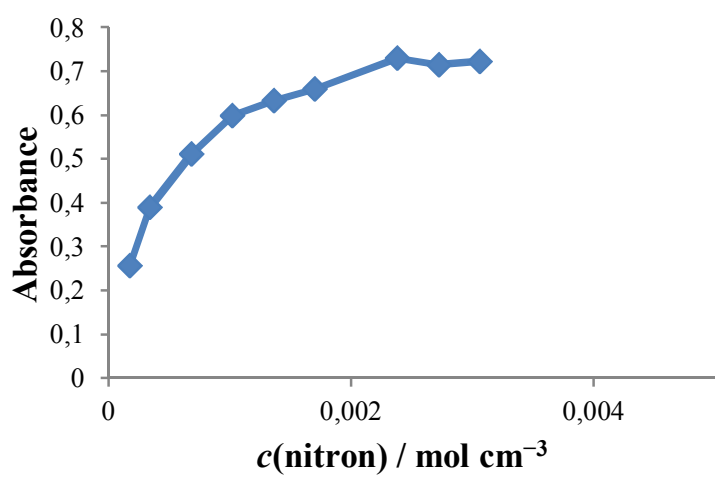

Figure 6. Absorbance of the extracted ternary Ga(III)-PAR-Nt complex vs. concentration of the $\mathrm{Nt}$ plots. $c(\mathrm{Ga})=$ $7.2 \times 10^{-6} \mathrm{~mol} \mathrm{dm}^{-3}, c(\mathrm{PAR})=2 \times 10^{-4} \mathrm{~mol} \mathrm{dm}{ }^{-3}, \mathrm{pH} 6.87$, $\lambda=510 \mathrm{~nm}, l=10 \mathrm{~mm}$.

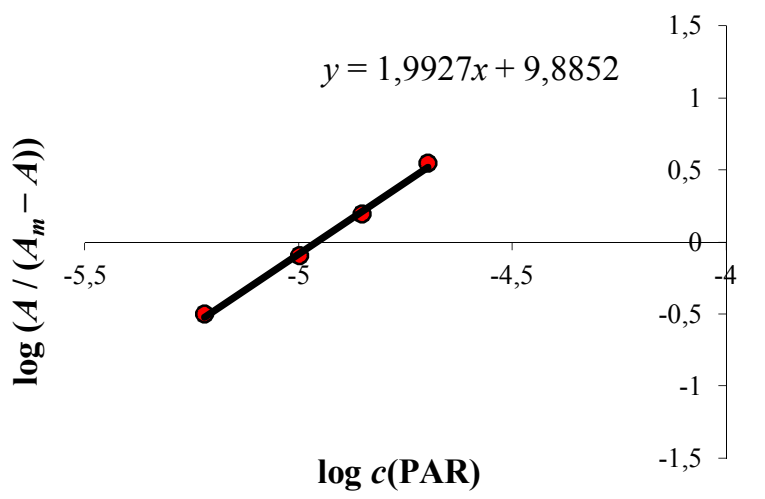

Figure 7. Determination of the PAR-to-Ga(III) molar ratio by the mobile equilibrium method. $c(\mathrm{Ga})=7.2 \times 10^{-6} \mathrm{~mol} \mathrm{dm}^{-3}$, $c(\mathrm{PAR})=2 \times 10^{-4} \mathrm{~mol} \mathrm{dm}^{-3}, \mathrm{pH} 6.87, \lambda=510 \mathrm{~nm}, l=10 \mathrm{~mm}$. 


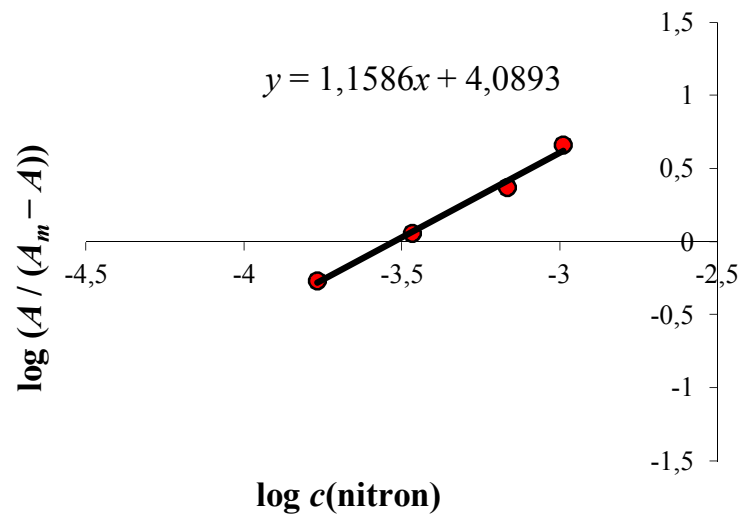

Figure 8. Determination of the Nitron-to-Ga(III) molar ratio by the mobile equilibrium method. $c(\mathrm{Ga})=7.2 \times 10^{-6} \mathrm{~mol} \mathrm{dm}^{-3}$, $c(\mathrm{Nt})=3.5 \times 10^{-4} \mathrm{~mol} \mathrm{dm}^{-3}, \mathrm{pH} 6.87, \lambda=510 \mathrm{~nm}, l=10 \mathrm{~mm}$.

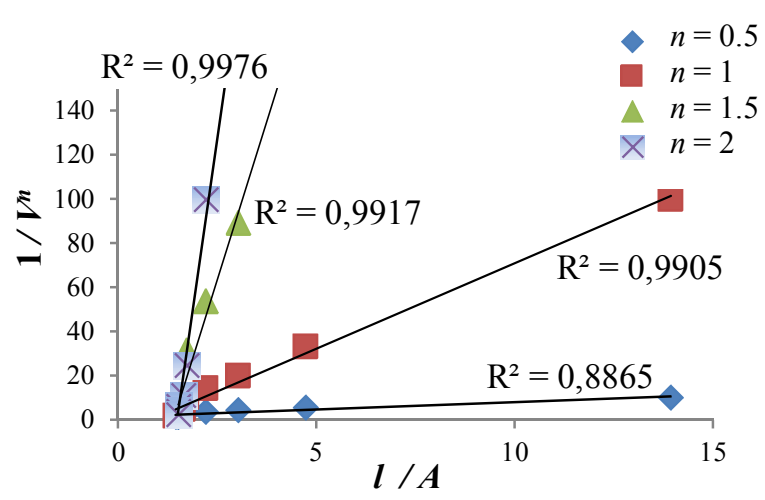

Figure 9. Determination of the Ga(III)-to-PAR molar ratios by the method of Asmus. $c(\mathrm{Ga})=7.2 \times 10^{-6} \mathrm{~mol} \mathrm{dm}^{-3}, c(\mathrm{PAR})=$ $2 \times 10^{-4} \mathrm{~mol} \mathrm{dm}^{-3}, \mathrm{pH} 6.87, \lambda=510 \mathrm{~nm}, l=10 \mathrm{~mm}$.

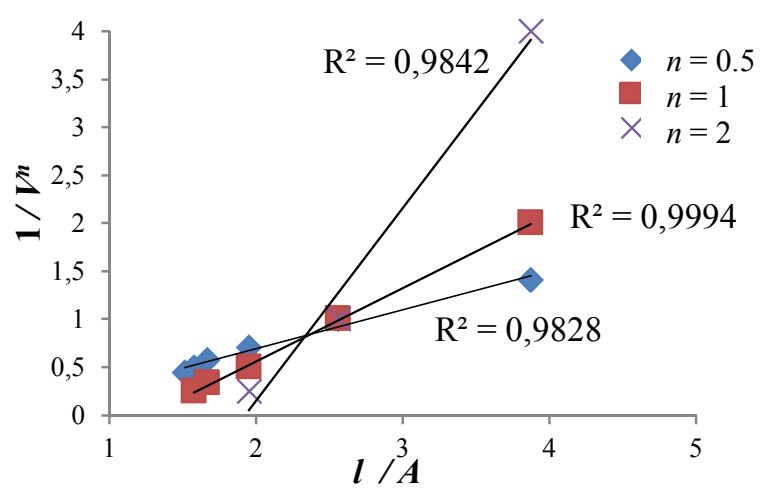

Figure 10. Determination of the Ga(III)-to-nitron molar ratios by the method of Asmus. $c(\mathrm{Ga})=7.2 \times 10^{-6} \mathrm{~mol} \mathrm{dm}^{-3}, c(\mathrm{Nt})=$ $3.5 \times 10^{-4} \mathrm{~mol} \mathrm{dm}^{-3}, \mathrm{pH} 6.87, \lambda=510 \mathrm{~nm}, l=10 \mathrm{~mm}$.

\section{Equilibrium Constants and Recovery}

The constant of association $\beta$ were calculated by mobile equilibrium method. ${ }^{21}$ The constant of distribution $K_{D}$, were determined in the above described procedure. The constant of extraction $\left(K_{e x}\right)$ and recovery factor $(R / \%)$ were determined by formulae $K_{e x}=K_{D} \times \beta$ and $R / \%=$ $100 \times K_{D} /\left(K_{D}+1\right)$, respectively. The results are present in Table 2.

\section{Beer's Law and Analytical Characteristics}

The adherence to Beer's law for Ga(III)-PAR-Nt-waterchloroform system was examined under the optimum extraction-spectrophotometric conditions (Table 1).

The linearity is observed up to $0.8 \mu \mathrm{g} \mathrm{cm}^{-3}$ of Ga. The molar absorptivity was calculated to be $(10.3 \pm$ $0.4) \times 10^{4} \mathrm{dm}^{3} \mathrm{~mol}^{-1} \mathrm{~cm}^{-1}$. This value could compete successfully with the ones obtained for similar PAR-containing complexes (Table 3). The limit of detection (LOD) and the limit of quantification (LOQ) were estimated. Sandell's sensitivity was calculated as well (Table 1).

\section{CONCLUSION}

Gallium(III) forms chloroform extractable ternary ionassociation complexes with 4-(2-Pyridylazo)-resorcinol (PAR) and 1,4-diphenyl-3-(phenyllamino)-1H-1,2,4triazole (nitron, Nt). The complex could be regarded as an ion associate between an intensively colored anion, $\left[\mathrm{Ga}(\mathrm{PAR})_{2}\right]^{-}$, in which gallium is +3 oxidation state, and a bulky hydrophobic cation (protonated nitron, $\mathrm{NtH}^{+}$).

The following equilibrium constants and analytical parameters are calculated: constant of extraction $\left(\log K_{e x}=6.28 \pm 0.07\right)$, constant of association $(\log \beta=4.98 \pm 0.05)$, constant of distribution $\left(\log K_{D}=1.30 \pm 0.02\right)$, recovery factor $(R / \%=95.17 \pm$ $0.02)$, apparent molar absorptivity $\left(\left(\varepsilon_{510}=(10.3 \pm\right.\right.$ $\left.0.4) \times 10^{4} \mathrm{dm}^{3} \mathrm{~mol}^{-1} \mathrm{~cm}^{-1}\right)$ ) for $\mathrm{Ga}(\mathrm{III})$ concentration up to $0.8 \mu \mathrm{g} \mathrm{cm} \mathrm{cm}^{-3}$, limit of detection (LOD = $0.072 \mu \mathrm{g} \mathrm{cm}^{-3}$ ), limit of quantification (LOQ = $\left.0.24 \mu \mathrm{g} \mathrm{cm} \mathrm{cm}^{-3}\right)$ and Sandell's sensitivity $(S S=$ $0.000675 \mathrm{ng} \mathrm{cm}^{-2}$ ).

The calculated equilibrium constants indicate that in the aqueous phase is formed, stable enough for this type of compounds, a ternary ion - associated complex, that is very well extracted into chloroform. These features, combined with analytical parameters give rise to claims that the analysis of gallium can be performed with high sensitivity and accuracy.

Table 2. Calculated values $(P=95 \%)$ of the extraction constant $\left(K_{\mathrm{ex}}\right)$, distribution constant $\left(K_{\mathrm{D}}\right)$, association constant $(\beta)$ and recovery factor $(R / \%)$

\begin{tabular}{ccccc}
\hline Extraction system & $\log \beta$ & $\log K_{\mathrm{D}}$ & $\log K_{\text {ex }}$ & $R / \%$ \\
\hline $\mathrm{Ga}(\mathrm{III})-\mathrm{PAR}-\mathrm{Nt}-\mathrm{H}_{2} \mathrm{O}$-chloroform & $4.98 \pm 0.05$ & $1.30 \pm 0.02$ & $6.28 \pm 0.07$ & $95.17 \pm 0.02$ \\
\hline
\end{tabular}


Table 3. Spectral characteristics of some extracted in organic solvent Ga-PAR complexes

\begin{tabular}{|c|c|c|c|c|}
\hline Additional reagent & Organic solvent & $\begin{array}{c}\text { Molar absorptivity / } \\
\mathrm{dm}^{3} \mathrm{~mol}^{-1} \mathrm{~cm}^{-1}\end{array}$ & $\lambda_{\max } / \mathrm{nm}$ & Ref. \\
\hline PAR + tetraphenylarsonium chloride & 1,2-dichlorobenzene & 8.20 & 510 & [6] \\
\hline $\mathrm{PAR}+$ pyridine + sodium acetate & $\begin{array}{l}\text { isopropyl ether }+ \\
\text { butyl acetate }\end{array}$ & 10.00 & 510 & {$[7]$} \\
\hline PAR + 2,3,5-triphenyltetrazolium chloride (TTC) & chloroform & 9.50 & 510 & {$[18]$} \\
\hline $\mathrm{PAR}+$ neotetrazolium chloride (NTC) & chloroform & 8.5 & 510 & {$[24]$} \\
\hline PAR + blue tetrazolium chloride (BTC) & chloroform & 8.5 & 510 & {$[24]$} \\
\hline $\mathrm{PAR}+$ nitro blue tetrazolium chloride $(\mathrm{NBT})$ & chloroform & 7.1 & 511 & {$[24]$} \\
\hline $\mathrm{PAR}+$ tetranitro blue tetrazolium chloride (TNBT) & chloroform & 6.2 & 513 & {$[24]$} \\
\hline $\begin{array}{c}\text { PAR + 2-(4-iodophenyl)-3-(4-nitrophenyl)-5-phenyl- } \\
\text { 2H-tetrazolium chloride (INT) }\end{array}$ & chloroform & 8.2 & 510 & {$[17]$} \\
\hline $\mathrm{PAR}+$ tetrazolium violet $(\mathrm{TV})$ & chloroform & 9.6 & 510 & {$[17]$} \\
\hline PAR + thiazolil blue tetrazolium (MTT) & chloroform & 9.5 & 515 & {$[19]$} \\
\hline $\mathrm{PAR}+$ nitron & chloroform & 10.3 & 510 & This work \\
\hline
\end{tabular}

The PAR and Nitron could complete successfully with many reagents for the spectrophotometric and liquid-liquid extraction for spectrophotometric determination of gallium(III).

Presented characteristics of the studied system give rise to claims that its application for the development of extraction-spectrophotometric method for determination of gallium, successfully compete described in the literature. ${ }^{17-19,24}$

\section{REFERENCES}

1. T. Biver, A. Boggioni, F. Secco, and M. Venturini, Langmuir 24 (2008) 36-42.

2. M. Blanco, J. Coello, H. Iturriaga, S. Maspoch, J. Riba, and E. Rovita, Talanta 40 (1993) 261-267.

3. C. D. Dwivmt, K. N. Munshi, and A. K. Dey, J. Inorg. Nucl. Chem. 28 (1966) 245-247.

4. M. Hniličková and L. Sommer, Fresenius J. Anal. Chem. 193 (1963) 171-178.

5. L. L. Kolomiets and I. V. Pyatnitskii, Ukr. Khim. Zh. 45 (1979) 62-65.

6. M. Široki and M. J. Herak, Anal. Chim. Acta 87 (1976) 193-199.

7. K. Bansho and Y. Umezaki, Bull. Chem. Soc. Japan 40 (1967) 326-329.

8. E. A. Biryuk, V. A. Nazarenko, and R. V. Ravitskaya, Zh. Anal. Khim. 27 (1972) 1934-1940.

9. M. A. Karve and S. M. Khopkar, Chem. Anal. (Warsaw) 38
(1993) 469-476.

10. K. Hagiwara, M. Nakane, Y. Osumi, E. Ishii, and Y. Miyake, Jpn. Anal. 10 (1961) 1379-1382.

11. M. Široki and M. J. Herak, J. Inorg. Nucl. Chem. 39 (1977) $127-$ 129.

12. I. Mori, Y. Fujita, and T. Matsuo, Anal. Lett. 32 (1999) 613-622.

13. C. P. Vibhute and S. M. Khopkar, Analyst 111 (1986) 435-439.

14. F. I. Lobanov, G. K. Nurtaeva, and E. E. Ergozhin, Ekstraktsiya kompleksov ionov metallov s piridinovymi oksiazosoedineniyami, Nauka, Alma-Ata, 1983, 5-75.

15. C. Farber, M. Leibold, C. Bruhn, M. Maurer, and U. Siemeling, Chem. Commun. 48 (2012) 227-229.

16. R. M. Porganichnaya, B. E. Reznik, V. V. Nerubashchenko, A. G. Zezyanova, and A. V. Tsevina, Zh. Anal. Khim. 30 (1975) 180-182.

17. K. B. Gavazov, K. T. Stojnova, T. S. Stefanova, G. K. Toncheva, V. D. Lekova, and A. N. Dimitrov Chemija 23 (4) (2012) 278 285

18. K. Stojnova and K. Gavazov, J. Mater. Sci. Eng. Sec. A. 2 (2012) 423-429.

19. K. T. Stojnova, K. B. Gavazov, G. K. Toncheva, V. D. Lekova, and A. N. Dimitrov, Cent. Eur. J..Chem. 10 (2012) 1262-1270.

20. P. V. Racheva, K. B. Gavazov, V. D. Lekova, and A. N. Dimitrov, Journal of Materials (2013), 7 pages.

21. Z. Zhiming, M. Dongsen, and Y. Cunxiao, J. Rare Earths 15 (1997) 216-219.

22. J. H. Yoe and A. L. Jones, Industrial and Engineering Chemistry 16 (1944) 111-115.

23. E. Asmus, Fresenius Z. Anal. Chem. 178 (1960) 104-116.

24. K. T. Stojnova, K. B. Gavazov, and V. D. Lekova, Acta Chim. Slov. 60 (2013) 390-396. 